\title{
STRATEGI KOMUNIKASI DALAM PEMBELAJARAN BAHASA INGGRIS (PENELITIAN ETNOGRAFI PADA SEKOLAH INTERNASIOANAL AIScho BSD City)
}

\author{
Arif Rahman \\ Universitas MH Thamrin, Jatinegara, Jakarta Timur \\ Email: Arifrahman0580@yahoo.com
}

\begin{abstract}
This study aims to investigate the communication strategies in English language learning conducted by the learnes of international students of SMP AIScho BSD City. This research conducts a qualitative approach with an ethnography method. The data of 27 learners' spoken speech were collected from observation by using audio recorder, field notes and unstructured interview. The data analisis were using performance analysis technique, a futher analysis based on actual speeches and linguistic behaviors.The analysis reveals that the learners employ communication strategies in English language learning consists of verbal communication strategy and nonverbal communication strategy. The finding futher shows that the learnes employ both communication strategies in terms of three reasons; keeping communication obsctacles, to govern language competence and strategic competence.
\end{abstract}

Keywords: $\quad$ communication strategy, Language competence, English language learning strategy.

\begin{abstract}
Abstak: Penelitian ini bertujuan untuk mengkaji strategi komunikasi dalam pembelajaran bahasa Inggris oleh siswa pada SMP Internasional AIScho BSD City. Penelitian ini menggunakan pendekatan kualitatif dengan metode ethnografi, adapun data dari 27 subjek penelitian dikumpulkan melalui pengamatan dengan menggunakan audio recorder, catatan lapangan dan wawancara tidak formal. Data penelitian kemudian dianalisis dengan menggunakan teknik analisis performansi yaitu, melakukan analisis berdasarkan tuturan yang terjadi secara alamiah dan kompetensi linguistik. Hasil penelitian menunjukan bahawa siswa SMP menggunakan dua strategi komunikasi yaitu, strategi komunikasi verbal dan strategi komunikasi nonverbal. Hasil penelitian ini juga menunjukan bahawa siswa menggunakan strategi komunikasi dengan dua karakteristik yaitu: untuk dapat mempertahankan jalanya komunikasi, untuk menyatakan maksud tertentu dan untuk menguasai kompetensi bahasa dan menguasai bentuk-bentuk tertentu sebagai kompetensi strategis.
\end{abstract}

Kata Kunci: strategi komunikasi, kompetensi bahasa, strategi belajar bahasa Inggris.

Penggunaan bahasa Inggris

sebagai bahasa kedua (B2) yang dituturkan oleh siswaa bahasa Indonesia sebagai bahasa pertama (B1) dalam kegiatan pembelajaran bahasa memiliki dua ciri yaitu, untuk mengatasi kendala dalam berkomunikasi dan menguasai kompetensi bahasa dan kompetensi komunikatif yang dituturkan menggunakan strategi tertentu. Penggunaan strategi komunikasi merupakan hal penting dalam konteks pembelajaran bahasa Inggris sebagai B2 untuk menjembatani kesenjangan antara pengetahuan bahasanya dan pengetahuan bahasa mitra tuturnya dalam proses komunikasi dan pengetahuan bahasa mitra tuturnya dalam proses komunikasi yang dihadapinya. Sejalan dengan statemen tersebut, Tarone, (2001: 20) berpendapat bahwa strategi komunikasi adalah teknis yang sistematis digunakan siswa untuk mengekspresikan idenya ketika mengalami kesulitan karena penguasaan bahasa yang belum sempurna.

Komunikasi yang dituturkan oleh siswa dalam interaksi pembelajaran merupakan media bagi pembelajaran 
untuk melatih dan mengembangkan pengetahuan bahasanya dan memaksimalkan kompetensi strategis. Dalam berkomunikasi seseorang berusaha menggunakan berbagai bentuk kebahasaan yang telah dikuasainya untuk menyatakan maksud dan pikirannya kepada orang lain. Dalam usaha untuk dapat berkomunikasi tersebut terdapat hal penting yang perlu dikaji, yaitu bagaimana cara siswa berkomunikasi dalam bahasa yang sedang dipelajarinya itu. Penyampaian pesan dalam kumunikasi oleh siswa yang menguasai bahasa target secara sempurna, dapat berlangsung dalam berbagai cara. Hal itu bergantung pada situasi dan kondisi ketika komunikasi berlangsung dan berbagai faktor lain yang berpengaruh, Corder, (1983: 15-19).

Strategi komunikasi menurut Faerch dan Kasper, (2003) merupakan "rencana sadar untuk memecahkan masalah yang diajukan seorang individu kepada dirinya sendiri untuk ia pecahkan sendiri di dalam mencapai tujuan komunikatif tertentu”. Corder (1983) menyatakan bahwa communication strategies are a systematic technique employed by speaker to exam bias meaning when faced with some difficulty. Sejalan dengan pendapat tersebut, secara lebih rinci Tarone mendefinisikan strategi komunikasi dalam dua versi, yaitu: (1) strategi komunikasi adalah upaya siswa secara sistematis untuk mengekspresikan maksud dalam bahasa target ketika ia tidak dapat membentuk atau memilih kaidah bahasa target dengan tepat dan (2) strategi komunikasi adalah upaya sadar siswa untuk mengkomunikasikan pikirannya ketika tatabahasa bahasaantara (interlanguage) tidak memadai untuk menyampaikan pikiran tersebut.

Dari uraian tersebut dapat disederhanakan bahwa strategi komunikasi merupakan cara yang digunakan penutur untuk menyatakan maksud ketika menghadapi kesulitan komunikasi akibat keterbatasan pengetahuan bahasa target yang mereka miliki. Berkaitan dengan pengertian tersebut, Tarone, (1983) mengemukakan beberapa ciri penanda penggunaan strategi komunikasi. Pertama, pembicara ingin mengkomunikasikan suatu maksud tertentu kepada mitra tutur. Kedua, pembicara merasa tidak dapat mengembangkan komunikasi karena keterbatasan linguistik dan sosiolinguistik untuk menyatakan suatu maksud. Ketiga, penutur memilih untuk menghindari komunikasi dan berusaha menggunakan cara tertentu untuk mengkomunikasikan maksud tertentu dan usaha ini terhenti 
apabila mitra tutur telah memahami maksud yang dikemukakannya.

Para peneliti terdahulu telah telah melakukan penelitian mengenai penggunaan strategi komunikasi dalam PBM, seperti Neimer (2012 :1-16) melakukan penelitian yang mengidentifikasi dan mengklasifikasi strategi komunikasi, tetapi dan menghubungkan strategi komunikasi dengan tingkat keefektifan penggunaannya. Hasil penelitiannya menunjukkan bahwa menggunakan strategi komunikasi lebih efektif ketika digunakan oleh siswa yang memiliki kontrol formal yang lebih besar terhadap B1. Selain Neimer, Meida (2013 :132-146) melakukan penelitian mengenai strategi komunikasi dalam pembelajaran bahasa asing. Pengunaan strategi ini mencakupi tipe strategi komunikasi verbal dan nonverbal oleh siswa asing yang belajar bahasa Indonesia. Ia menyimpulkan bahwa siswa yang cenderung menggunakan strategi komunikasi nonverbal dalam bentuk gesture, mimik, dan gerakan tubuh karena keterbatasan reportoire mereka dalam menyampaikan pesan kepada mitra tuturnya, dan siswa yang menggunakan tipe trategi verbal dalam bentuk alih kode, pengulangan serta pengungkapan tuturan sendiri, untuk mempertahankan jalanya komunikasi dan menguasai bentuk tuturan.
Penelitian lain yang dianggap paling relevan dengan penelitian ini adalah penelitian yang dilakukan oleh Werdianingsih, (2007 : 359-362) dan Drajati (2013: 214) yang meneliti mengenai strategi pemerolehan kompetensi pragmatik siswa. mereka memfokuskan pada strategi komunikasi dan strategi belajar bahasa. Strategi komunikasi dibagi dalam dua tipe yaitu: strategi komunikasi verbal dan strategi komunikasi noverbal. Selanjutnya dalam kesimpulanya mereka mengungkapkan bahawa penggunaan strategi komunikasi, selain untuk mempertahankan jalannya komunikasi juga untuk menyatakan maksud tertentu dan menguasai bentukbentuk tuturan yang dapat memaksimalkan proses pemerolahan bahasa.

Berdasarkan urain penelitian terdahulu serta hasil pengamatan pendahuluan dilapangan terhadap tuturan siswa SMP dalam pembelajaran bahasa Inggris sesuai dengan teori yang dikemukakan oleh para pakar seperti: Faerch dan Kasper, (2003); Bialystok, (1983) Tarone, (1983); Ellis, (1994); Naremore dan Hopper, (1997) Turian dan Altenberg, dan Brown, (2000) DI dalam Werdianingsih, (2007: 51) terdapat dua kategori strategi komunikasi yang digunakan oleh siswa yaitu: 1) strategi 
komunikasi nonverbal, dan 2) strategi komunikasi nonverbal dan verbal oleh komunikasi verbal. para pakar yang digunakan dalam

Keseluruhan kategorisasi tipe dan penelitian ini adalah sebagai berikut:

variasi tipe seta klarifikasi strategi

Tabel A. Penggunaan Strategi Komunikasi Nonverbal dan Verbal oleh Siswa SMP

\begin{tabular}{|c|c|c|}
\hline Kategori Strategi Komunikasi & $\begin{array}{l}\text { Tipe dan Variasi Strategi } \\
\text { Komunikasi oleh Siswa SMP }\end{array}$ & $\begin{array}{l}\text { Klasifikasi Variasi Strategi } \\
\text { Komunikasi oleh Para Pakar }\end{array}$ \\
\hline 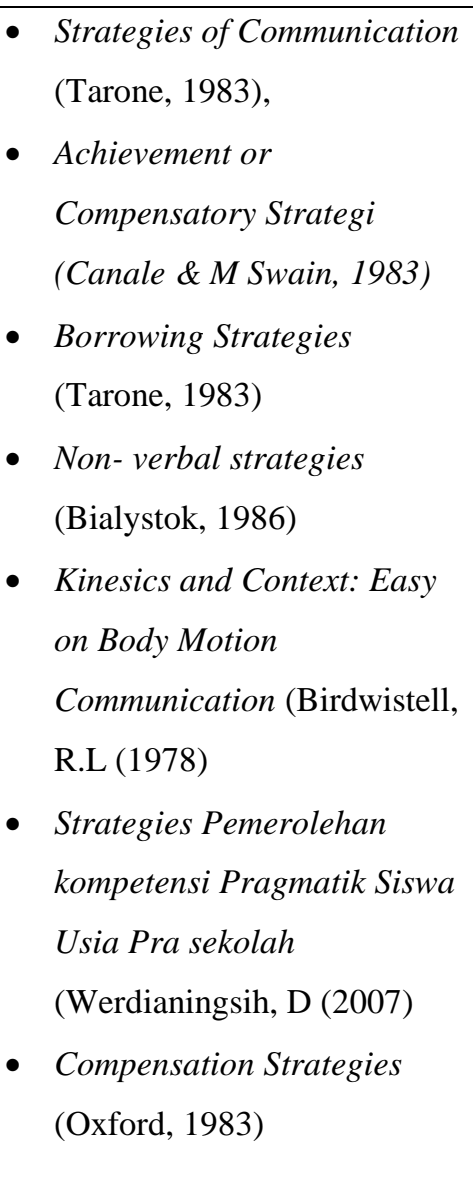 & $\begin{array}{l}\text { A. Strategi Komunikasi } \\
\text { NonVerbal: } \\
\text { 1. Strategi komunikasi bentuk } \\
\text { Isyarat } \\
\text { 2. Strategi komuniksi bentuk } \\
\text { gerakan tubuh } \\
\text { 3. Strategi komunikasi bentuk } \\
\text { menirukan objek. } \\
\text { B. Strategi komunikasi Verbal } \\
\text { 1. Strategi komunikasi bentuk } \\
\text { tuturan; } \\
\text { a) Pengalihan Kode Tuturan } \\
\text { b) Penggunaan Pemaparan } \\
\text { Tuturan } \\
\text { c) Penciptaan Kata Kreatif } \\
\text { 2. Strategi Komunikasi Bentuk } \\
\text { Pengungkapan isi tuturan } \\
\text { a) Pemaparan Maksud } \\
\text { b) Pemgalihan topik tuturan }\end{array}$ & $\begin{array}{l}\text { - Using mime and gesture } \\
\text { (Tarone 1983) } \\
\text { - Non-verbal (Canale \& } \\
\text { Swain, 1983) } \\
\text { - Non- linguistik mimes } \\
\text { (Hasrup \& Philipson, 1983) } \\
\text { - Pengantar Ilmu Komunikasi } \\
\text { (Cangara, Hafied, 2007) } \\
\text { - Human ommunication, } \\
\text { (Tubbs, L. Stewart, 2003) } \\
\text { Interlanguage } \\
\text { Communication: (Faerch dan } \\
\text { Kasper, 1983) }\end{array}$ \\
\hline
\end{tabular}

(Sumber: Modifikasi dari Werdianingsih, $2007: 346$ )

Berdasarkan penjelasan tersebut, penelitian ini bertujuan mengkaji strategi komunikasi dalam pembelajaran bahasa Inggris oleh siswa Sekolah Menengah Pertama. Secara khusus fokus penelitian ini adalah mengkaji 1) penggunaan strategi komunikasi nonverbal dalam pembelajaran bahasa Inggris, dan 2) penggunaan strategi komunkasi verbal dalam pembelajaran Bahasa Inggris.

\section{METODE PENELITIAN}

Penelitian ini menggunakan pendekatan kualitatif dengan metode etnografi (Etnografy Approach). Pendekatan kualitatif digunakan untuk 
menemukan gambaran secara utuh, natural dan mendalam terkait dengan peristiwa tindak tutur diperankan oleh siswa. Emzir, (2012:145) menyatakan Penelitian etnografi dilandasi oleh filsafat fenomenologi yang berusaha mendeskripsikan fenomena kultural atau pandangan hidup subjek yang diteliti seperti cara mereka berinteraksi, berfikir dan berkomunikasi. Menurut Spadley, (1980: 28-34) prosedur penelitian kualitatif dengan metode etnografi dilakukan dalam beberpa siklus yang terdiri dari enam langkah; 1) pemilihan suatu project entnografi, 2) pengajuan pertanyaan etnografi, 3) pengumpulan data etnografi, 4) pembuatan suatu rekaman etnografi, 5) analisis data etnografi, dan 6) penulisan sebuah etnografi. Instrumen penelitian ini adalah peneliti berlaku sebagai instrument inti dengan instrumen pendukung berupa pedoman pengamatan dan alat perekam elektronik pencatatan lapangan dan wawancara nonformal.

Data penelitian ini dikumpulkan dari hasil pengamatan dan catatan lapangan berupa strategi komunikasi dalam pembelajaran bahasa Inggris oleh siswa SMP. Adapun subjek penelitian ini adalah melibatkan 27 siswa SMP kelas VII Program Internasional AIScho BSD City Kota Tangerang Selatan. Penentuan jumlah subjek pada penelitian ini adalah ada dua hal yaitu: jumlah subjek diambil dinggap jumlah maksimal dan cukup memadai untuk menjawab masalah penelitian ini. Penelitian ini mengikuti langkah-langkah analisis data menurut Miles dan Huberman, (1992: 29) yaitu: 1) seleksi data (data selection), 2) reduksi data (data reduction), 4) penyajian data (data display), dan 4) menarik kesimpulan dan verifikasi (coclution drawing and verifycation). Adapaun keabsahan data penilitian dengan melakukan uji kredibilitas melalui perpanjangan pengamatan, trianggulasi serta diskusi teman sejawat.

\section{HASIL PENELITIAN}

\section{A. Penggunaan Strategi Komunikasi Nonverbal dalam Pembelajaran Bahasa Inggris oleh Siswa Sekolah Menengah Pertama}

Berdasarkan hasil temuan penelitian diketahui bahwa penggunaan strategi komunikasi nonverbal memiliki hubungan yang sangat kuat dalam meningkatkan motivasi belajar warga belajar melalui interaksi yang terjadi secara terarah dan berkesinambungan. Siswa dapat menerima dan memahami maksud yang ingin disampaikan oleh mitra tutur serta menyampaikan apa yang ada dalam pikirannya melalui komunikasi nonverbal berupa isyarat dan gerakan, 
mimik, serta gerakan menirukan objek dalam interaksi pembelajaran bahasa. Penggunaan Strategi komunikasi nonverbal dilakukan oleh siswa SMP dalam pembelajaran bahasa Inggris memiliki karakteristik yang terlihat pada tipe dan variasi tipe, faktor penyebab, dan fungsi. Karakteristik dari keseluruhan penggunaan tipe dan variasi tipe, faktor penyebab, dan fungsi penggunaan strategi komunikasi nonverbal oleh siswa VIII SMP AlScho BSD City terlihat pada tabel 5.1 berikut ini:

Tabel B. Penggunaan Strategi Komunikasi Nonverbal dalam Pembelajaraan Bahasa Inggris oleh Siswa SMP

\begin{tabular}{|c|c|c|c|}
\hline $\begin{array}{l}\text { Tipe Strategi } \\
\text { Komunikasi }\end{array}$ & $\begin{array}{l}\text { Variasi tipe Strategi } \\
\text { Komunikasi }\end{array}$ & Aspek Kompetensi Bahasa & Keterangan \\
\hline $\begin{array}{l}\text { Strategi } \\
\text { Komunikasi } \\
\text { Nonverbal }\end{array}$ & $\begin{array}{l}\text { 1) Penggunaan Strategi } \\
\text { komunikasi bentuk } \\
\text { isyarat } \\
\text { 2) Strategi } \\
\text { komunikasi bentuk } \\
\text { gerakan } \\
\text { 3) Strategi } \\
\text { komunikasi bentuk } \\
\text { peniruan Objek }\end{array}$ & $\begin{array}{l}\text { a) Menyatakan permintaan } \\
\text { b) Manyatakan Pertanyaan } \\
\text { c) Menyatakan Dukungan } \\
\text { d) Menyatakan fakta } \\
\text { e) Memperjelas pesan yang } \\
\text { disampikan } \\
\text { f) Menyatakan Pembenaran } \\
\text { g) Menyatakan maksud agar } \\
\text { pesan dapat dapat dipahami }\end{array}$ & $\begin{array}{l}\text { Siswa SMP kelas VIIl } \\
\text { menggunakan strategi } \\
\text { komunikasi nonverbal } \\
\text { yang direlaisasikan ke } \\
\text { dalam tiga variasi untuk } \\
\text { menyatakan aspek } \\
\text { kompetensi strategis dan } \\
\text { untuk menyatakan } \\
\text { aspek kompetensi bahasa }\end{array}$ \\
\hline
\end{tabular}

(Sumber: Modifiaksi dari Werdianingsih, 2007: 343)

Berdasarkan uraian penggunaan strategi komunikasi nonverbal yang dipaparkan pada tabel 4.1 diperoleh gambaran bahwa Karakteristik penggunaan strategi komunikasi nonverbal oleh siswa SMP yang direalisasikan kedalam tiga variasi tipe strategi komunikasi dinyatakan untuk: (1) menguasai aspek kompetensi strategis yaitu: strategi komunikasi bentuk isyarat, strategi komunikasi bentuk gerakan tubuh, dan strategi komunikasi bentuk peniruan objek. (2) untuk menyatakan tujuh aspek kompetensi bahasa adalah 
menyatakan permintaan, manyatakan pertanyaan, menyatakan suruhan, menyatakan dukungan, dan menyatakan pembenaran. Dari kajian ini diperoleh gambaran mengenai Karakteristik strategi komunikasi yang digunakan oleh siswa SMP kelas VIII dalam pembelajaran bahasa Inggris.

Penggunaan strategi komunikasi nonverbal oleh siswa dalam pembelajaran bahasa Inggris disebabkan oleh berbagai faktor yaitu: (1) tingkat penguasaan bahasa yang diperoleh dari stimulus baik di luar pembelajaran formal maupun pembelajaran formal, (2) sumber problem komunikasi merupakan konten tuturan yang dikomunikasikan, kepribadian siswa, (4) tujuan komunikasi, dan (5) situasi belajar.

$$
\text { Hasil kajian ini juga }
$$
menggambarkan bahwa strategi komunikasi nonverbal merupakan bentuk strategi yang efektif bagi siswa digunakan dalam pembelajaran bahasa untuk memaksimalkan proses penguasaan kompetensi bahasanya pada tahap awal. Cara ini dilakukan oleh siswa yang belum mahir atau pun yang sudah mahir berbahasa Inggris dalam bentuk penggunaan bentuk-bentuk strategi yang berbeda-beda.

\section{B. Penggunaan Strategi Komunikasi Verbal dalam pembelajaran} Bahasa Inggris oleh Siswa Sekolah Menengah Pertama

Penggunaan Strategi komunikasi bentuk verbal dalam pembelajaran bahasa Inggris dilakukan oleh siswa SMP terdiri atas dua variasi tipe yaitu; strategi pengukapan bentuk tuturan dan strategi pengungkapan isi tuturan. Penggunaan Strategi komunikasi verbal dilakukan oleh siswa SMP dalam pembelajaran bahasa Inggris memiliki karakteristik yang tampak pada tipe dan variasi tipe, faktor penyebab, dan fungsi penggunaannya.

Karakteristik dari keseluruhan penggunaan tipe dan variasi tipe, faktor penyebab dan fungsi penggunaan strategi komunikasi verbal dilakukan oleh siswa SMP kelas VIII SMP AlScho BSD City terlihat pada tabel 5.3 berikut ini : 
Tabel C. Penggunaan Strategi Komunikasi Verbal dalam pembelajaran Bahasa Inggris oleh Siswa SMP

\begin{tabular}{|c|c|c|c|c|c|}
\hline \multicolumn{2}{|c|}{$\begin{array}{l}\text { Kategori strategi } \\
\text { Komunikasi }\end{array}$} & \multicolumn{2}{|c|}{$\begin{array}{l}\text { Variasi Tipe Strategi } \\
\text { Komunkasi }\end{array}$} & \begin{tabular}{|l|} 
Fungsi \\
Strategi \\
komunikasi
\end{tabular} & Keterangan \\
\hline \multirow{6}{*}{$\begin{array}{l}\text { Komu- } \\
\text { nikasi } \\
\text { Verbal }\end{array}$} & \multirow{4}{*}{$\begin{array}{l}\text { Penggunaan } \\
\text { staregi } \\
\text { komunikasi } \\
\text { bentuk tuturan }\end{array}$} & $\begin{array}{l}\text { 1) Pengalihan } \\
\text { code dalam } \\
\text { tuturan }\end{array}$ & $\begin{array}{l}\text { Penggunaan } \\
\text { clausa/kalimat }\end{array}$ & $\begin{array}{l}\text { - Menyatakan } \\
\text { Penolakan } \\
\text { - Menyatakan } \\
\text { fakta } \\
\text { - Menyata- } \\
\text { penjelasankan } \\
\text { maksud }\end{array}$ & \multirow{6}{*}{$\begin{array}{l}\text { Siswa SMP kelas } \\
\text { VIII menggunakan } \\
\text { strategi komunikasi } \\
\text { verbal } \\
\text { direalisasikan } \\
\text { dalam } 2 \text { tipe } \\
\text { strategi besar yang } \\
\text { selanjutnya } \\
\text { direalisasikan } \\
\text { dalam } 5 \text { variasi tipe } \\
\text { strategi tertentu } \\
\text { dan digunakan } \\
\text { untuk menguasai } \\
\text { aspek kompetensi } \\
\text { strategis dan untuk } \\
\text { menyatakan } 12 \\
\text { aspek kompetensi } \\
\text { bahasa }\end{array}$} \\
\hline & & \multirow{2}{*}{$\begin{array}{l}\text { 2) Pemaparan } \\
\text { tuturan }\end{array}$} & $\begin{array}{l}\text { Penggunaan } \\
\text { kata-kata } \\
\text { sendiri }\end{array}$ & $\begin{array}{l}\text { - Menyatakan } \\
\text { penjelasan } \\
\text { - Menyatakan } \\
\text { makna tuturan }\end{array}$ & \\
\hline & & & $\begin{array}{l}\text { Penggunaan } \\
\text { analogi }\end{array}$ & $\begin{array}{l}\text { - } \text { Menyatakan } \\
\text { penjelasan } \\
\text { - Menyatakan } \\
\text { maksud dan } \\
\text { saran }\end{array}$ & \\
\hline & & $\begin{array}{l}\text { 3) Penciptaan } \\
\text { kata kreatif }\end{array}$ & $\begin{array}{l}\text { - Pengguna-an } \\
\text { Bagian } \\
\text { Kata/Frase } \\
\text { - Pengguna-an } \\
\text { kata sinonim }\end{array}$ & $\begin{array}{l}\text { - Menyatakan } \\
\text { fakta } \\
\text { - Menyatakan } \\
\text { fakta }\end{array}$ & \\
\hline & \multirow{2}{*}{$\begin{array}{l}\text { Penggunaan } \\
\text { staregi } \\
\text { komunikasi } \\
\text { bentuk } \\
\text { pengungkapan } \\
\text { isi tuturan }\end{array}$} & $\begin{array}{l}\text { 4) Penajaman } \\
\text { maksud } \\
\text { tuturan }\end{array}$ & $\begin{array}{l}\text { Penajaman } \\
\text { maksud } \\
\text { tuturan }\end{array}$ & $\begin{array}{l}\text { - Menyatakan } \\
\text { penjelasan } \\
\text { maksud tuturan }\end{array}$ & \\
\hline & & $\begin{array}{l}\text { 5) Pengalihan } \\
\text { topik tuturan }\end{array}$ & $\begin{array}{l}\text { Pengalihan } \\
\text { topik tuturan }\end{array}$ & $\begin{array}{l}\text { - Menyatakan } \\
\text { penjelasan } \\
\text { alasan }\end{array}$ & \\
\hline
\end{tabular}

(Sumber: Modifikasi dari Werdianingsih, $2007: 343$ )

Tabel 4.2 menyajikan uraian kedalam dua tipe strategi komunikasi dan penggunaan strategi komunikasi verbal lima variasi tipe strategi komunikasi, oleh siswa SMP yang direalisasikan dinyatakan untuk: (1) menyatakan aspek 
kompetensi strategis yaitu: a) strategi komunikasi bentuk tuturan, terdiri dari; pengalihan kode, pemaparan tuturan, penciptaan kata kreatif penajaman, maksud tuturan, dan pengalihan topik tuturan, b) strategi komunikasi bentuk pengungkapan isi tuturan, terdiri dari; penajaman maksud tuturan dan pengalihan topik tuturan, (2) untuk menyatakan dua belas aspek kompetensi bahasa yakni untuk menyatakan penolakan, menyatakan fakta, menyatakan penjelasan maksud, menyatakan makna suka, menyatakan klarifikasi, menyatakan maksud dan saran, menyatakan fakta, dan menyatakan penjelasan alasan. Dari kajian ini diperoleh gambaran mengenai karakteristik penggunaan strategi komunikasi yang digunakan oleh siswa SMP kelas VIII dalam pembelajaran bahasa Inggris.

Berdasarkan temuan penelitian ini karakteristik penggunaan komunikasi verbal yang oleh siswa dalam pembelajaran bahasa Inggris terdapat dua ciri yakni terjadi pada praktek berkomunikasi secara alamiah dan berfungsi untuk mengatasi permasalahan dalam berkomunikasi disebabkan keterbatasan penguasaan bahasa siswa. Penggunaan strategi komunikasi verbal oleh siswa dalam pembelajaran bahasa Inggris, sebagaimana diuraikan pada strategi komunikasi nonverbal juga disebabkan oleh berbagai faktor yaitu: (1) tingkat penguasaan bahasa yang diperoleh dari stimulus baik di luar pembelajaran formal maupun pembelajaran formal. Ellis \& Hatch, (1994) mengatakan bahwa tingkat penguasaan bahasa siswa berperan penting dalam pemilihan dan penggunaan tipe dan variasi tipe strategi komunikasi tertentu. Salah satu aspek yang mendukung tingkat penguasaan bahasa siswa adalah input bahasa yang diterima dan yang dikuasai siswa baik dari luar kelas maupun dalam kelas. (2) sumber problem komunikasi merupakan konten tuturan yang dikomunikasikan. Pengaruh faktor sumber problema komunikasi terhadap penggunaan strategi komunikasi siswa terbukti pada penggunaan strategi yang didasarkan pada pengaruh bahasa lain yang dikuasai siswa (B1) dan strategi yang didasarkan pada bahasa target (B2). (3) kepribadian siswa: Kepribadian siswa memberikan pengaruh terhadap penggunaan strategi komunikasi pada penuturan strategi permintaan bantuan yang dilakukan secara langsung kepada mitra tuturnya. (4) tujuan komunikasi: Tujuan komunikasi memberikan pengaruh pada penggunaan strategi komunikasi yang diwujudkan dengan semua bentuk strategi komunikasi yang digunakan. Semua tipe dan variasi tipe strategi komunikasi yang digunaan siswa berorientasi pada ketercapaian tujuan 
komunikasi, Keller dan Rech, (1998:315) dan (5) situasi belajar. Situasi belajar dalam lingkungan bahasa yang alamiah memberikan pengaruh terhadap keleluasaan siswa dalam menggunakan strategi komunikasi. Hal ini ditunjukkan dengan tidak adanya kendala bagi siswa untuk memanfaatkan berbagai strategi komunikasi sesuai dengan kebutuhannya.

Temuan penelitian tentang faktor-faktor penyebab penggunaan strategi komunikasi nonverbal maupun verbal siswa dalam pemerolehan bentukbentuk bahasa melibatkan faktor internal dan faktor lingkungan bahasanya. Dengan demikian, temuan tersebut mendukung pandangan teori interaktif dalam proses pemerolehan bahasa oleh pakar antara lain Clark dan Clark, (2007:342).

Penggunaan strategi komunikasi siswa menunjukkan adanya proses interaktif pada pemerolehan kompetensi bahasa B2, yakni adanya keterlibatan faktor kematangan perangkat bawaan bahasa siswa dan masukan bahasa yang dipajankan kepada siswa. Faktor kematangan perangkat bawaan bahasa siswa ini merupakan piranti yang berperan penting sebagai pemroses internal dalam struktur mental mereka, yakni sebagai penyunting dan penyaring masukanmasukan bahasa yang berasal dari lingkungan bahasanya dan sebagai pengorganisasi yang berperan dalam menginternalisasikan masukan-masukan bahasa yang terdapat dalam lingkungan sekitarnya menjadi sistem kaidah yang dikuasai siswa. Adapun faktor masukan bahasa yang dipajankan kepada anak mempengaruhi penguasaan kompetensi strategis dan pemerolehan kompetensi bahasa anak terkait dengan pemnanfaatan bentuk-bentuk tuturan yang dipajankan kepada siswa untuk mengungkapkan maksud-maksud tertentu kepada mitra tuturnya dalam berkomunikasi.

Dari penelitian ini diperoleh gambaran adanya perkembangan kompetensi bahasa siswa yang ditunjuk dengan penggunaan bentuk-bentuk tuturan yang sejalan dengan perkembangan kompetensi strategis siswa. Menurut Steinberg, (1982: 3-27) perkembangan bahasa terjadi dalam tiga tahap, yaitu: (1) tahap penamaan dan holoprastis, (2) tahap telegrafis, dan (3) tahap transformasional dan morfemis.

Berdasarkan penjelasan tersebut, penggunaan strategi komunikasi nonverbal maupun verbal oleh siswa berfungsi untuk menyatakan bentukbentuk tuturan dan untuk mengatasi problem komunikasi yang dihadapinya ketika mereka mengalami kesulitan dalam menyatakan bentuk-bentuk tuturan untuk menyatakan berbagai maksud kepada 
mitra tuturnya, yaitu bentuk-bentuk tuturan untuk (1) menyatakan penjelasan, (2) menyatakan fakta, (2) menyatakan pertanyaan, (3) menyatakan permintaan, (4) menyatakan penolakan, menyatakan pendapat, (6) menyatakan alasan, (7) menyatakan nasihat, (8) menyatakan perintah, (9) menyatakan keluhan, (10) menyatakan maksud, (11) menyatakan penegasan, (12) menyataan ide, dan (13) menyatakan simpulan.

Fungsi penggunaan strategi komunikasi tersebut menunjukkan adanya perkembangan kompetensi strategis dan bahasa siswa (lihat tabel 4.1 dan 4.2). Perkembangan fungsi penggunaan strategi komunikasi sesuai dengan kompetensi bahasa siswa ini membuktikan adanya pengaruh perbedaan psikologis dan sosiobudaya terhadap penggunaan strategi komunikasi dan pemerolehan kompetensi bahasa. Proses bahasa siswa dipengaruhi oleh faktor sosiobudaya masyarakat tutur B1 dan B2 serta faktor afektif anak sebagai penutur bahasa, baik dilingkungan sekolah maupun dilingkungan keluarga. Temuan ini berimplikasii pada perlunya penanaman norma budaya sejak dini kepada anak sehingga anak memiliki kepekaan dalam menggunakan bentukbentuk kebahasaan yang sesuai dengan konteksnya. Hal ini sejalan dengan pernyataan Ferdinan (dalam NowakFabrykowski dan Shkandri, 2005: 284-
313), pengintegrasian dan pengadaptasian budaya perlu dilakukan untuk membantu siswa dalam menggunakan bahasa sesuai dengan norman-norma penggunaanya.

Sebagai penutur dwibahasawan Indonesia-Inggris, penggunaan strategi komunikasi dalam pembelajaran bahasa Inggris dipengaruhi oleh faktor sosialbudaya masyarakat tutur B1 dan B2. Pemerolehan kompetensi bahasa tersebut dipengaruhi oleh proses penyerapan budaya B1 dan B2. Dengan kata lain, keberhasilan siswa dalam menguasai kompetensi strategi dan bahasa ditentukan oleh keberhasilannya dalam mengakulturasikan dirinya pada bahasa target yang dipelajarinya. Untuk memperoleh gambaran yang lebih mendalam tentang pengaruh faktor sosial budaya dalam penggunaan strategi komunikasi tersebut perlu dilakukan penelitian lebih lanjut. Oleh sebab itu, berdasarkan temuan ini direkomendasikan bagi peneliti berikutnya untuk melakukan penelitian dengan fokus kajian tentang pengaruh faktor sosial budaya terhadap penguasaan kompetensi strategis dan pemerolehan kompetensi bahasa siswa sekolah menengah.

\section{SIMPULAN}

Strategi komunikasi merupakan cara-cara yang dilakukan oleh siswa untuk menyatakan maksud ketika menghadapi 
kendala dalam berkomunikasi karena keterbatasan kemampuan siswa berkomunikasinya. Dengan penggunaan berbagai bentuk strategi komunikasi, siswa dapat melatih dan mengembangkan kompetensi strategis dan kompetensi bahasanyanya sesuai dengan tinggkat penguasaan bahasa mereka. Penggunaan strategi komunikasi pada siswa SMP memiliki karakteristik yang berbeda meskipun terdapat kesamaan-kesamaan.

Penggunaan strategi komunikasi verbal oleh siswa direalisasikan dalam tiga bentuk strategi yaitu: strategi bentuk isyarat, gerakan tubuh, dan peniruan objek. Hal ini dilakukan siswa karena faktor keterbatasan penguasaan siswa terhadap bentuk-bentuk tuturan yang tepat untuk menyatakan maksud pada mitra tuturnya. Fungsi pokok strategi komunikasi nonverbal adalah untuk menjaga kelangsungan komunikasi. Fungsi pokok penggunaan strategi ini adalah mempertahankan kelangsungan komunikasi yang disebabkan adanya rasa khawatir melakukan kesalahan dalam menggunakan bahasa Inggris.

Penggunaan strategi komunikasi verbal oleh siswa mereflesikan upaya siswa untuk memanfaatkan bentuk-bentuk tuturan yang telah dikuasainya untuk berkomunikasi. Strategi penggunaan bentuk verbal ini digunakan siswa dalam dua tipe, yaitu: (1) strategi penggunaan bentuk tuturan dan (2) strategi penggunaan isi tuturan. Penggunaan strategi ini disebabkan oleh faktor kedwibahasaan siswa dan keterbatasan penguasaan kosakata yang tepat untuk menyatakan maksud ketika percakapan berlangsung. Penggunaan strategi tersebut berfungsi untuk menjaga kelangsungan komunikasi dan mengefektifkan tujuan komunikas. Dengan terjaganya kelangsungan komunikasi, siswa dapat memperoleh kesempatan untuk melakukan praktek menggunakan bahasa untuk meningkatkan kompetensi pragmatiknya. Strategi pengungkapan isi tuturan digunakan siswa karena kemampuan berbahasannya masih terbatas, terutama kemampuan dalam memahami dan menggunakan bentukbentuk tutran yang diperlukan dalam proses komunikasi itu. Fakta penggunaan strategi nonverbal menunjukan bahwa siswa telah mampu mengatasi kendala komunikasi dengan cara yang dimilikinya dengan tepat. Ketepatan penggunaan bentuk verbal menunjukan perkembangan kompetensi strategis yang tampak pada kemudahan mitra tutur untuk memahami maksud tuturan siswa. Hasil kajian penelitian ini diproleh gambaran tentang penggunaan startegi komunikasi pada masyarakat tutur yang sebenarnya yang 
mengandung norma-norma dan kaidah sosiokultural.

Berdasarkan uraian hasil temuan, terdapat beberapa keterbatasan dalam penelitian ini, kepada peneliti selanjutnya untuk mengadakan penelitian sejenis dengan mengambil wilayah penelitian yang lebih luas, sampel yang lebih banyak dan menggunakan rancangan penelitian yang lebih kompleks seperti etnografi komunikasi melalui triangulasi pengamatan, wawancara dan dokumentasi, menggunakan mata pelajaran yang lebih banyak lagi, jugamelakukan penelitian pada tingkat pendidikan yang lebih tinggi seperti pada mahasiswa Universitas, sehingga dapat ditemukan hasil yang lebih optimal dan bisa digeneralisasikan pada wilayah yang lebih luas.

\section{DAFTAR PUSTAKA}

Bialystok, E. Some Factors in the Selection and Implementation of Communication Strategies. Di dalam C. Faerch dan G. Kasper (Eds), Strategies in Interlanguage Communication. London: Longman, 1983.

Brown, H.D. Principles of Language Learning and Teaching. New York: Pearson Education, Inc, 2007.

Emzir. Metodologi penelitian pendidikan: kuantitatif dan kualitatif Ed. 1-2-
- Jakarta: PT RajaGrafindo

Persada, 2012.

Canale, Michael. \& Merril, Swain. Theoretical bases of communicative approaches to second language teaching and testing. Applied Linguistics, 1, 147. 1980.

Clark, E.V. First Language Acquisition. New York: Cambridge University Press, 2003.

Corder, J. Strategies of Communication. Di dalam C. Faerch dan G. Kasper (Eds), Strategies in Interlanguage Communication. London: Longman, 1983.

DÖrnyei, Z. On the Teachibility of Communication

Strategies.TESOL, 1995.

Ellis, R. The study of Second Language Acquisition. Oxford: Oxford University Press, 1994.

Faerch dan G, Kasper (Eds). Strategies in Interlanguage Communication. London: Longman, 2003.

Hymes, D. H. On Communicative Competence. Di dalam C.J. Brumfit dan $\mathrm{K}$. Johnson, The Communicative Approach to Language Teaching (h. 5-26). Oxford: Oxford University Press, 1979.

Miles, Mattheew, B., A. Michael Huberman. Analisis Data Kualitatif, penerjemah : Tjetjep Rohendi Rohidi, UI Press, Jakara, 1992.

Nowas-Fabrykowski, dan Shkandrij. The symbolic of Bilingual Children: Digression on Language Acquisition, Culture and the Process of Thingking. Journal of 
Instructional Psycology. Vol. 3 Issues: 4, 2005.

Oxford, R.L. Language Learning Startegies: What every teacher should Know. Boston, Mass: Hainle \& Hainle Publisher, 1990.

Spradley, James P. Participant Observation. New York : Holt, Rinehart and Winston, 1980.

Steinberg, DD. Psycoliguistics Language Mind and Word. London: Logman, 1982.
Tarone, E., Cohen, A., \& Dumas, G. In Faerch \& G. Kasper (Eds.), A Closer Look at Some Interlanguage Terminology: A Framework for Communication Strategies, 1983.

Tarone, E. dan Yule, G. Focus on the language learner. Oxford: Oxford University Press, 2001.

Werdiningsih, D. Strategies Pemerolehan kompetensi Pragmatik Anak Usia Prasekolah. Malang: Unpublished Disertation, 2007. 